\title{
GENETIC PARAMETERS OF FIRST LACTATION MILK YIELD AND FERTILITY TRAITS IN BROWN SWISS CATTLE
}

\author{
Aziz Şahin ${ }^{1 *}$, Zafer Ulutaş², Asiye Yılmaz Adkinson³ ${ }^{3}$ Robert W. Adkinson ${ }^{3}$ \\ ${ }^{1}$ Department of Animal Science, Ahi Evran University, 40100 Kırşehir, Turkey \\ ${ }^{2}$ Department of Animal Production and Technologies, Nigde University, 51240 Nigde, Turkey \\ ${ }^{3}$ Department of Animal Science, Erciyes University, 38100 Kayseri, Turkey \\ •Corresponding author: aziz.sahin@ahievran.edu.tr
}

\begin{abstract}
This research was carried out to estimate variance components and genetic parameters for first lactation milk yield (lactation milk yield, 305-day milk yield, lactation length, and dry period) and some fertility traits (calving interval, gestation length and number of services per conception) of Brown Swiss cattle reared at Konuklar State Farm located in Konya province, Turkey. Data were collected on milk yield traits of 3,769 first lactation Brown Swiss cattle during the period from 1990 to 2008. Variance components, genetic parameters, breeding values, and genetic correlations were estimated using multiple trait derivative free restricted maximum likelihood (MTDFREML) fitting an animal model. Heritability estimates were $0.26,0.25,0.10,0.06,0.07,0.06$ and 0.03 for lactation milk yield (LMY), 305-day milk yield (305 DMY), lactation length (LL), dry period (DP), calving interval (CI), gestation length (GL), and number of services per conception (NSC), respectively. Genetic correlations between milk yield and fertility traits ranged from 0.31 to 0.95 and phenotypic correlations ranged from -0.026 to 0.75 . Breeding values were estimated and used to characterize genetic trends across the time period investigated. The results showed that the first lactation milk yield traits can be used as selection criteria for development of effective genetic improvement programme in Turkish Brown Swiss cattle. In addition, the results indicate the essential for scheming an effective schedule for growth of genetic variability to improve the milk yield traits of Brown Swiss cattle in this farm by way of selection.
\end{abstract}

Key words: Brown Swiss, heritability, milk yield, dry period, lactation length

Animal breeders are aware of the importance of highly nutritious and affordable animal products in the human diet and continued research in animal breeding will help ensure these needs are met. Breeding research has been conducted and will continue to be conducted in order to help reach these goals. The Brown Swiss breed is well known and used throughout the world and is an important genetic resource for 
Turkey. Brown Swiss cattle were first imported to Turkey from Austria and Hungary in 1925. In subsequent years, Brown Swiss cattle have been imported at different times from various countries (Akman, 1998). Of the current Turkish population of $12,386,337$ cattle, $19.61 \%$ are classified as domestic, $39.05 \%$ improved and $41.34 \%$ crossbred. Total milk production in Turkey is 13,543,674 tons with $91.69 \%$ coming from cattle. Milk productivity of cattle in Turkey needs improvement with an average of 2,899 $\mathrm{kg}$ per cow per year (TUIK, 2013). There are numerous causes for this level of production. First are the effects of environmental conditions such as feed availability, poor housing systems, and veterinary care. Second, effective selection programms have not been adopted and there has been little emphasis on quantitative genetic evaluation. To increase milk production it is essential to improve environmental conditions and genetic quality. Improvement of performance through selection is mainly dependent upon the effective use of additive genetic variation and accurate estimation of genetic parameters for the traits to be selected. These genetic parameters are essential tools in animal breeding research and in the design and application of practical breeding programmes (Tosh and Kemp, 1994; Kumlu, 2003).

First lactation is considered as test lactation because the cow's body is still developing. First lactation yield increases in importance as an indicator of a long-term tendency towards shortening the length of productive life in cattle (Reklewski et al., 2004; Sawa and Krezel-Czopek, 2009). Correct and reliable information on genetic parameters is of vital importance for planning appropriate selection and breeding schemes for the genetic development of dairy cattle. Knowledge of first lactation traits allows the breeder to forecast the subsequent lactation performance of cattle as it is highly correlated with future performance (Jairath et al., 1995). In addition, selection interval is reduced using first lactation information. Results of studies related to heritability of first lactation yield traits are in Table 1.

Table 1. Heritabilities of first lactation milk yield traits

\begin{tabular}{lcccccl}
\hline \multicolumn{1}{c}{ Breeds } & LMY & 305 DMY & LL & DP & \multicolumn{1}{c}{ Researcher } \\
\hline Holstein & 0.15 & 0.30 & 0.10 & 0.09 & Khattab and Atil (1999) \\
Holstein & 0.22 & - & - & - & Ulutaş et al. (1999) \\
Brown Swiss & 0.44 & - & 0.33 & 0.25 & Sing et al. (1995) \\
Holstein & 0.27 & - & 0.02 & - & Tekerli and Koçak (2009) \\
Brown Swiss & 0.23 & - & - & - & Tilki et al. (2009) \\
Karan Swiss & 0.45 & 0.78 & 0.05 & 0.40 & Kumar and Bhatnagar (1989), \\
& & & & & Herbert and Bhatnagar (1989) \\
Sahiwal & 0.11 & 0.11 & 0.09 & 0.05 & Rehman et al. (2008) \\
Holstein & 0.20 & 0.13 & 0.05 & - & Ozyurt and Akman (2009) \\
Holstein & 0.33 & - & - & - & Makgahlela et al. (2007) \\
\hline
\end{tabular}

LMY: lactation milk yield, 305 DMY: 305-day milk yield, LL: lactation length, DP: dry period. 
Consequently, first lactation parameters are used as selection standards (Da et al., 1992). Some authors have concluded that production of dairy cattle in all lactations is determined by more or less the same genes (Meyer, 1984; Bagnicka et al., 2004). For these reasons, first lactation yields are used as efficient selection criteria for lifetime production. Genetic correlation estimates between first and second lactation milk yields in Holstein cattle were reported as 0.86 (Visscher and Thompson, 1992). Dong and Van Vleck (1989) reported that the genetic correlation between first and second lactation milk yield was 0.82 . Estimates of genetic correlations of 0.73 between first and second lactation milk yields and 0.63 between first and third lactation milk yields have been reported (Unalan and Cebeci, 2004). Comparable results by Swalve and Van Vleck (1987) indicated that genetic correlations were 0.86 between first and second lactation milk yield and 0.85 between first and third lactation milk yields. Visscher and Thompson (1992) estimated that genetic correlations were 0.86 between first and second lactation milk yield. Genetic correlations between first and second lactation milk yield were reported as 0.92 and 0.87 between first and third lactation, respectively (Bahreini Behzadi et al., 2013). Genetic correlations among the first and subsequent lactation milk yields of Jersey cattle were reported as 0.68 , $0.67,0.63,0.60,0.59$ and 0.55 , respectively. All genetic correlations were large and statistically significant $(\mathrm{P}<0.01)$. Large genetic correlations among lactation performance indicate that first lactation milk yield of cows would be effective for selection of breeding stock (Unalan and Çankaya, 2010). There is limited research on genetic parameters in the literature for first lactation yield traits of Brown Swiss cattle.

The goals of this research were to estimate the variance components, genetic parameters and correlations for first lactation milk yield, fertility traits, and breeding values for 305-day milk yield of Brown Swiss cattle reared at the Konuklar State Farm in Turkey.

\section{Material and methods}

\section{Data}

Data consists of first lactation records of 3,769 cattle born from 1988 and onwards and noted from 1990 to 2008. Records used in this research were gathered for the Brown Swiss cattle kept at the Konuklar State Farm. Preliminary analyses, irregular data affected by illnesses or abortion and cattle having calving interval less than 310 days and greater than 650 days, and lactation length less than 220 days and greater than 550 days were omitted from the records (Kumlu and Akman, 1999). A lactation record was removed if the animal died during lactation. Calving months were categorized into four seasons: December to February (winter), March to May (spring), June to August (summer), and September to November (autumn). Milk records were pre-adjusted to a 305-day lactation length. Production traits studied were lactation milk yield, 305-day milk yield (305-DMY), lactation length (LL), dry period (DP), calving interval (CI), gestation length (GL), and number of services per conception (NSPC). 


\section{Statistical analyses}

Preliminary analyses were done for milk yield and reproductive traits to identify the significant effects. The General Linear Model Method in Minitab Version 12 (1998) was used for analyses. The model contained random animal effects. Fixed effects added in the model were calving year, calving season, and age of calving as a covariate for all traits. Genetic parameters, variance components, breeding values and genetic correlations were estimated using the DXMUX sub-program developed by Boldman et al. (1995) to perform single and multi-trait analysis by MTDFREML. Single-trait animal models were used to estimate genetic parameters, variance components and breeding values (only for first lactation 305-day milk yield). Multiple traits animal models were used to estimate genetic correlations among the traits. The convergence criteria for all analyses was $1 \times 10^{-9}$. Estimates of breeding values (EBV) for 305-day milk yield and genetic trend were calculated. The EBVs were then fitted using a fixed effect model having birth year to obtain least squares solutions for plotting genetic trends. Descriptive statistics of the records are in Table 2.

Table 2. Frequencies of observations used for genetic parameter estimates

\begin{tabular}{lcc}
\hline & Description & Total \\
\hline Cattle in data & 3769 \\
Dams in data & 1107 \\
Sires in data & 540 \\
Year (1990-2008) & 15 \\
Seasons & 4 \\
\hline
\end{tabular}

The statistical models used to estimate variance components, coefficient of heritabilities, and correlations for each trait are given below.

Model (for first lactation records)

The equation can be denoted in matrix form as:

$$
y=X b+Z a+e
$$

where:

$y$ is a vector of observation,

$b$ is a vector of fixed effects with incidence matrix $X$,

$\mathrm{a} \sim \mathrm{N}\left(0, \sigma^{2} A\right)$ is a vector of random animal effects with incidence matrix $Z$,

$\mathrm{e} \sim \mathrm{N}\left(0, I_{\mathrm{n}} \sigma^{2}\right)$ is a vector of random residual effects.

The distributional properties were assumed to be as follows:

$$
V\left[\begin{array}{l}
a \\
e
\end{array}\right]=\left[\begin{array}{cc}
\sigma_{a}^{2} A & 0 \\
0 & I \sigma_{e}^{2}
\end{array}\right]
$$


where:

$\sigma^{2}$ is the additive genetic variance,

$Z, \sigma^{2}$ is the residual variance,

$A$ is the additive genetic relationship matrix,

$I_{c}$ and $I_{n}$ are identity matrices of order equal to the number of cattle and the number of records (one record for each animal), respectively.

Genetic trends were estimated by averaging the estimated breeding values (EBVs) by birth year of cattle and regressing the averages against year. Graphs of genetic trends were created using Excel ${ }^{\circledR}$. The regression technique in Minitab Version 12 (1998) was used to determine genetic, phenotypic, and environmental trends.

\section{Results}

\section{Heritabilities}

Averages obtained were lactation milk yield $(5,194.9 \pm 43.1 \mathrm{~kg}), 305$-day milk yield $(4,943.00 \pm 43.200 \mathrm{~kg})$, lactation length $(320.14 \pm 2.210 \mathrm{~d})$, dry period $(79.59 \pm 2.220 \mathrm{~d})$, calving interval $(401.93 \pm 2.510 \mathrm{~d})$, gestation length $(281.79 \pm 0.310 \mathrm{~d})$, and number of services per conception (1.33 \pm 0.030$)$. Resulting highest heritability estimates were for lactation milk yield and 305-day milk yield, while the lowest were for dry period, calving interval, gestation length and number of services per conception. Variance components indicated that additive genetic variance $\left(\sigma_{\mathrm{a}}^{2}\right)$ was fairly high for lactation milk yield and 305-day milk yield resulting in high heritabilities for these traits. The variance components and genetic parameters for first lactation traits are in Table 3. Heritability estimates for lactation milk yield, 305-day milk yield, lactation length, dry period, calving interval, gestation length and number of services per conception were $0.26,0.25,0.10,0.06,0.07,0.06$ and 0.03 , respectively. Standard errors were low $(<0.0001)$ for all traits.

Table 3. Genetic parameters for first lactation milk yield and fertility traits

\begin{tabular}{l|rrrr}
\hline \multirow{2}{*}{ Parameters } & \multicolumn{4}{c}{ Milk yield traits } \\
\cline { 2 - 5 } & LMY $(\mathrm{kg})$ & 305 DMY $(\mathrm{kg})$ & LL $($ day $)$ & DP $($ day $)$ \\
\hline Phenotypic variance $\left(\sigma_{\mathrm{p}}^{2}\right)$ & $1,116,079.25$ & $1,095,398.23$ & $3,099.50$ & $2,076.03$ \\
Additive genetic variance $\left(\sigma_{\mathrm{a}}^{2}\right)$ & $291,576.02$ & $277,417.47$ & 307.02 & 122.36 \\
Residual variance $\left(\sigma_{\mathrm{e}}^{2}\right)$ & $824,503.10$ & $814,213.17$ & $2,660.27$ & $1,811.65$ \\
Heritability $\left(h^{2}\right)$ & 0.26 & \multicolumn{4}{c}{0.25} & 0.10 & 0.06 \\
\hline \multicolumn{1}{c}{ Parameters } & Fertility traits & NSC (number) \\
\cline { 2 - 5 } & CI $($ day $)$ & GL (day) & 0.79 \\
Phenotypic variance $\left(\sigma_{\mathrm{p}}^{2}\right)$ & $4,228.8$ & 53.91 & 0.02 \\
Additive genetic variance $\left(\sigma_{\mathrm{a}}^{2}\right)$ & 276.0 & 2.98 & 0.77 \\
Residual variance $\left(\sigma_{\mathrm{e}}^{2}\right)$ & $3,952.8$ & 50.93 & 0.03 \\
Heritability $\left(h^{2}\right)$ & 0.07 & 0.06 & \multicolumn{3}{c}{} \\
\hline
\end{tabular}

LMY: lactation milk yield, 305 DMY: 305-day milk yield, LL: lactation length, DP: dry period, CI: calving interval, GL: gestation length, NSC: number of services per conception, standard errors were below 0.0001 for all traits. 


\section{Genetic and phenotypic correlations}

Estimates of genetic (upper diagonal) and phenotypic (lower diagonal) correlations ( $\mathrm{r}_{\mathrm{g}}$ and $\mathrm{r}_{\mathrm{p}}$, respectively) among the traits (LMY, $305 \mathrm{DMY}, \mathrm{LL}, \mathrm{DP}$ and CI) studied are presented in Table 4. Genetic and phenotypic correlations between milk yield and fertility traits were positive except between LL and DP. Genetic correlations between milk yield and fertility traits ranged from -0.31 to 0.95 and phenotypic correlations between milk yield and fertility traits ranged from -0.026 to 0.75 .

Table 4. Estimates of genetic (upper diagonal) and phenotypic (lower diagonal) correlations between production and reproductive traits

\begin{tabular}{l|c|c|c|c|c}
\hline & LMY & 305 DMY & LL & DP & CI \\
\hline LMY & - & 0.95 & 0.93 & 0.10 & 0.69 \\
305 DMY & 0.75 & - & 0.85 & 0.16 & 0.68 \\
LL & 0.66 & 0.70 & - & -0.31 & 0.92 \\
DP & 0.012 & 0.024 & -0.026 & - & 0.44 \\
CI & 0.14 & 0.13 & 0.62 & 0.60 & - \\
\hline
\end{tabular}

LMY: lactation milk yield, 305 DMY: 305-day milk yield, LL: lactation length, DP: dry period, CI: calving interval, GL: gestation length, NSC: number of services per conception.

\section{Genetic trends and breeding values}

Breeding values for 305-day milk yields of individual animals were estimated using first lactation performance information. The genetic trend was determined for 305-day milk yield by linear regression of average estimated breeding value (EBV) on year. Estimated breeding values were defined and are in Figure 1. The genetic trend for 305-day milk yield across years was $6.88 \mathrm{~kg} /$ year and significant.

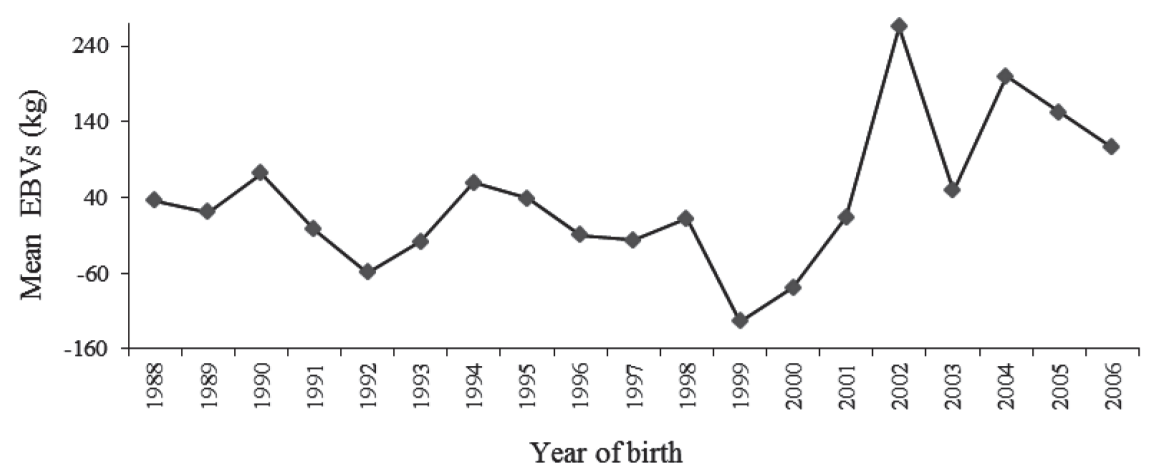

Figure 1. Mean EBVs of first lactation 305-day milk yield according to year 


\section{Discussion}

\section{Heritabilities}

The heritability estimate for lactation milk yield was 0.26 (Table 3 ). This result was consistent with findings of Sahin et al. (2012). Estimates of heritability for dry period, lactation length, calving interval, gestation length and number of services per conception were lower than lactation milk yield and 305-day milk yield. In this research, the heritability for lactation milk yield was lower than reported by Sing et al. (1995), Makgahlela et al. (2007) and Zavadilová and Štípková (2012), but was closer to the value of 0.23 reported by Tilki et al. (2009). The finding in research using Holstein yield records was higher than some of the present research results (Ulutas et al., 1999; Khattab and Atil, 1999; Ozyurt and Akman, 2009), but was closer to Tekerli and Kocak's findings (2009). Makgahlela et al. (2007) reported a heritability estimate for lactation milk yield in Holsteins of 0.33 . In reported research, the heritability of first lactation milk yield of Jersey cattle was estimated to be 0.28 (Unalan and Cankaya, 2010) and 0.38 (Missanjo et al., 2013). In this study, the heritability estimate of 0.25 for 305-day milk yield is similar to Toghiani (2012) and Sahin et al. (2012). This value is lower than some values reported in different countries (Kumar and Bhatnagar, 1989; Herbert and Bhatnagar, 1989; Khattab and Atil, 1999) and higher than others (Rehman et al., 2008; Ozyurt and Akman, 2009). Ptak et al. (2001) reported a heritability estimate for 305-day milk yield of 0.24 . Unalan and Cebeci (2004) determined the heritability for 305-day milk yield in Holstein cattle to be 0.29 . In the present research the estimated heritability of lactation length was 0.10 and is consistent with the values which Khattab and Atil (1999) reported in Holstein cattle and with the value which Rehman et al. (2008) reported in Sahiwal cattle. This result is lower than Sing et al. (1995) stated and is higher than the values of Tekerli and Kocak (2009), Ozyurt and Akman (2009) and Sahin et al. (2012). For Sahiwal cattle in India, heritability estimates varied from 0.00 to 0.52 for lactation milk yield, and 0.00 to 0.19 for lactation length (Sharma et al., 1987; Sing et al., 1988). In this research, the heritability estimate for dry period was 0.06 . This is close to the values reported by Khattab and Atil (1999) and Rehman et al. (2008). Higher estimates of heritability for dry period were reported by many authors, ranging from 0.13 to 0.40 (Kumlu and Akman, 1999; Ptak et al., 2001; Makgahlela et al., 2007; Rehman et al., 2008). However, Wall et al. (2003) and Gonzalez and Alenda (2005) reported lower heritabilities for dry period ranging from 0.03 to 0.08 . The foremost portion of variation in lactation length and dry period is due to non genetic factors and significant response could be expected by improving environmental conditions such as nourishing and management systems. Therefore, improving the environmental conditions could lead to a significant decrease in length of dry period. Makuza and McDaniel (1996) suggested that the low heritability for dry period (DP) indicated that temporary environmental influences were much greater than genetic influences or permanent environmental effects. Khalil et al. (1994) concluded that, due to low heritability for lactation yield and dry period (LMY and DP) a selection index based on paternal half-sister groups would not allow lactation yields to play a major role in selection programmes. 
The heritability of lactation length and dry period in dairy cattle is lower than many other economically important traits (LMY and 305 DMY). The low heritabilities of these traits illustrate that a major part of the variation in these characters are environmental and selection would be not effective in bringing about genetic improvement. This was also reported by Atil et al. (2001). In this research, the heritabilities for first lactation length, lactation milk yield and 305-day milk yield were moderate. Therefore, selection for first lactation milk yield and 305-day milk yield will be more effective than selection for yield characteristics with lower heritabilities. But, it is not true to say that genetic improvement is not possible as increasing the heritabilities in the herd will increase genetic variance and also genetic improvement. Most heritability literature estimates for dry period and lactation length are low. Current findings indicate that heritabilities for dry period and lactation length are low in the Brown Swiss cattle studied. These findings indicate that the variation observed is more a result of environmental conditions than genetic differences. This being the case, genetic improvement would not be easily or quickly obtained using standard selection practices.

Heritability estimates for calving interval (0.07) in this investigation agree with those of Muir et al. (2004), Tekerli and Kocak (2009) and M'Hamdi et al. (2011). The heritability estimate of calving interval in the present exploration was very low, indicating that the trait was mostly affected by environmental agents. Therefore, improvement in the trait may best be achieved through suitable management. The heritability estimate obtained in this investigation was higher than some in the current literature (Wall et al., 2003; Chagunda et al., 2004; Ilatsia et al., 2007). Campos et al. (1994) reported a heritability for calving interval of 0.021 . This conclusion is lower than findings of Toghiani (2012). In the present research, heritability of calving interval was low (0.07), which was consistent with previous estimates (Veerkamp et al., 2001; Kadarmideen et al., 2003).

In the present study, heritability was estimated for services per conception (0.03). This result is similar to other estimates (0.03 and 0.027) (González-Recio and Alenda, 2007; M'Hamdi et al., 2011). Heritability for services per conception was higher than 0.01 reported by Chonkasikit (2002) and Ilatsia et al. (2007). This value is also lower than findings of Chagunda et al. (2004).

Estimated heritability was 0.06 (Table 3 ) for gestation length. The present estimate is similar to values of 0.05 and 0.07 reported by Zulkadir and Boztepe (2003) and Toghiani (2012), respectively. Heritability for gestation length was higher than that found by Erdem (1997) and Chagunda et al. (2004).

The heritability estimate for services per conception was low (0.03), and within the range of the estimates of Singh et al. (1997) in Indian Holstein population $(0.06 \pm 0.11)$, Menendez and Dempfle (1998) in Cuban Friesian crosses (0.03), and Hayes et al. (1993) in Canadian Friesian crossbred population. However, some researchers declared higher estimates of 0.18 in Friesian crosses including Al-Salman (1985) and in Shahiwal crosses by Khan et al. (1992). The low heritability implies that genetics have negligible contribution to variation in the trait and management practices may influence improvement in the trait more than selection. Therefore, care 
should be taken in estrus detection and timing of insemination, semen quality and nutritional status of the animal to improve the trait.

Heritabilities were moderate for milk yield, and low for lactation length and calving interval. This is in agreement with the findings of many investigators (Campos et al., 1994; Jairath et al., 1995; Ojango and Pollot, 2001).

The moderate heritabilities for lactation milk yield and 305-day milk yield indicate that there is potential for improvement of these traits through selection. Heritability estimates of $0.10,0.06,0.07,0.06$ and 0.03 were attained for lactation length, DP, CI, GL and NSC, respectively. These estimates indicated low genetic to environmental variance ratios for lactation traits and reflected differences in their response to the existing environmental conditions.

The low heritability estimate for CI is in agreement with many other studies on Holstein-Friesian cattle (Veerkamp et al., 2001; Wall et al., 2003). However, higher estimates were described for Holstein-Friesian cattle in Kenya (Rege, 1991; Ojango and Pollot, 2001) and Florida, USA (Campos et al., 1994). The low heritability estimate for CI indicates that significant improvement through selection is attainable only through enhanced accuracy of selection by, for example, incorporating information on correlated traits (Wall et al., 2003; Kadarmideen, 2004).

\section{Genetic and phenotypic correlations}

Genetic correlations between LMY and 305 DMY each with CI were positive. Lara et al. (1989) and Muir et al. (2004) stated that milk yield was positively correlated with CI. Conversely, genetic correlations between these traits were negative (Khattab and Atil, 1999) and the genetic correlation between LL and CI was positive. Similarly, this correlation was determined to be positive (Ulutas et al., 2008). This indicated that higher milk yield was related with longer LL. The phenotypic correlations between LMY and 305 DMY, with LL were 0.70 and 0.66 , respectively. These findings are in agreement with those of Tuzemen et al. (1999) who determined high and positive phenotypic correlation between these traits in Holstein cattle. The correlation between LL and DP was negative. Negative phenotypic correlations $\left(\mathrm{r}_{\mathrm{p}}\right)$ between LL and DP indicate that cattle with shorter DP will have long LL. On the other hand, Atil et al. (2001) reported negative phenotypic correlation between 305 DMY and dry period in Holstein cattle. Genetic correlation between DP and LL was negative, whereas the correlations between LL and each of 305 DMY and DMY were positive. The genetic correlations between LMY and 305 DMY procured in the present study were positive and high (0.95). These results are similar to the findings (0.94) reported by Duru and Tuncel (2004) and Sahin et al. (2012) in Turkish Holsteins. Genetic correlations between first lactation milk yield and lactation length have been reported from 0.23 to 0.95 (Javed, 1999; Sahin et al., 2012).

\section{Genetic trend and breeding values}

Genetic trends were defined using regression of breeding values on years. Irregular fluctuations in 305-day milk yield of breeding values were observed. The genetic trend for 305-day milk yield was estimated to be $6.88 \mathrm{~kg} /$ year and was different from zero. Breeding values for 305-day milk yields were negative in some years, 
whereas breeding values for 305-day milk yield were positive in others. Genetic trend slope $(6.88 \mathrm{~kg} /$ year $)$ detected in the present investigation was smaller than the value found by Araújo et al. (2003). Tilki et al. (2009) stated that no positive and negative breeding values for 305 -day milk yields were observed across years. This was to be expected, since there was no intentional selection for 305-day milk yield being practiced on the farm during the era investigated. Changes in breeding values across years fluctuated being both positive and negative. Causes of these fluctuations are not known from this research, but could have resulted from the use of bulls with unknown breeding values. Selection of bulls for breeding in Turkey is often based upon pedigree information and phenotypic observations rather than more reliable estimates of breeding value such as proofs. Similar results were reported for Gelemen State Farm Friesian cattle by Ulutas et al. (1999), and for Kenyan Ayshire cattle by Amimo et al. (2007). These researchers attributed the low rate of genetic progress to selection on the basis of phenotypic values.

\section{Conclusions}

Heritability estimates for first LMY and 305 DMY indicate that these traits can be improved genetically through selection in the Turkish Brown Swiss cattle population. Selection on CI, DP, LL, GL and NSC is, however, likely to achieve slow progress, due to its low heritability. There is a need to enhance the accuracy of selection for these traits by increasing information used in their evaluations. Estimates of genetic parameters for Turkish Brown Swiss cattle were consistent with those described throughout earlier investigation. Estimates of genetic trends across the 20year period studied indicated the need for improved breeding programmes. Selection and mating based upon reliable measures of breeding value offer great opportunity for improved productivity of Brown Swiss cattle in Turkey.

As a result of the moderate heritability estimates for lactation milk yield and 305 DMY, it can be concluded that genetic development of milk yield can be attained through selective breeding. Therefore these two traits may be preferred by breeders as selection criteria for development of effective genetic improvement programmes.

\section{Acknowledgements}

Authors are thankful to the Republic of Turkey Ministry of Food, Agriculture and Livestock and General directorate of Agriculture Enterprises.

\section{References}

A k m a n N. (1998). Pratik Sı̆̆ır Yetiştiriciliği (in Turkish), Türk Ziraat Mühendisleri Birliği Yayını, Ankara, pp. 1-6.

A 1 - S a $1 \mathrm{~m}$ a n M.H. (1985). Genetic relationships of reproductive performance and production of Holstein cattle. Indian J. Anim. Sci., 55 : 351-353.

A m i mo J.O., Wakhungu J.W., In y angala B.O., Mos i R.O. (2007). The effects of non-genetic factors and estimation of genetic and phenotypic parameters and trends for milk yield in Ayrshire cattle in Kenya. Livest. Res. Rural Develop. 19, http://www.lrrd.org/lrrd19/1/amim19013.htm (05.09.2010). 
Araúj o C.V., D e Torres R., D e A., Rennó F.P., P ereira J.C., P ereira C.S., Araújo S.I., Filho R., De A.T., Silva H.C., R ennó L.N., Kais er F., Da R. (2003). Genetic trend in productive traits to Brown Swiss breed. R. Bras. Zootec., 32 (Supl. 2): 1872-1877.

A til H., Khat t a b S.A., Yaku p oğlu C. (2001). Genetic analysis for milk traits in different herds of Holstein Friesian cattle in Turkey. On Line J. Biol. Sci., 1: 737-741.

B a g n i c k a E., D is t 1 O., H a r man n H., L u k a s z e w i c z M. (2004). Heritabilities of and genetic correlations between the dairy traits in goats estimated in first and later lactations. Anim. Sci. Pap. Rep., 22: 205-213.

Bahreini Behzadi M.R., A mini A., A s laminejad A.A., Tahmoorespour M. (2013). Estimation of genetic parameters for production traits of Iranian Holstein dairy cattle. Livest. Res. Rural Develop., 25 Article \#156. Retrieved July 16, 2013, from http://www.lrrd.org/lrrd25/9/bahre25156.htm.

B old man K.G., Krie s e L.A., Van Vle c k L.D., K a c man S.D. (1995). A manual for use of MTDFREML. USD-ARS, Clay Center, Nebraska, USA.

C a m p o s M.S., W 11 c ox C.J., B e c err 1 C.M., D 1 z A. (1994). Genetic parameters for yield and reproductive traits of Holstein and Jersey cattle in Florida. J. Dairy Sci., 77: 867-873.

Cha gund a M.G.G., B runs E.W., Wollny C.B.A., King H.M. (2004). Effect of milk yieldbased selection on some reproductive traits of Holstein Friesian cows on large-scale dairy farms in Malawi. Livest. Res. Rural Develop., 16.

Ch o $\mathrm{nk}$ a s 1 k 1 t N. (2002). The impact of adaptive performance on Holstein breeding in Nothern Thailand. Georg-August-University, Göttingen, Germany (PhD Thesis).

D a Y., Gros s man M., M ist zal I., Wigg a n s G.R. (1992). Estimation of genetic parameters for somatic cell score in Holsteins. J. Dairy Sci., 75: 2265-2271.

D o n g M.C., Van V le c k L.D. (1989). Correlations among first and second lactation milk yield and calving interval. J. Dairy Sci., 72: 1933-1936.

Duru S., Tuncel E. (2004). The correlations between dry period, service period and age at first calving with some milk yield traits in Holstein Friesian cattle. Universty of Uludağ. J. Agri. Sci., 18: 69-79.

E r d e m H. (1997). Gökhöyük Tarım İşletmesinde yetiştirilen Siyah Alaca Sığırların süt ve döl verim özellikleri ve bu özelliklere ait bazı parametrelerin tahmini üzerine bir araştırma (in Turkish). (Doktora Tezi), Ondokuzmayıs Üniv, Zootekni Bölümü, Samsun.

Gonzalez-R e c i o O., A lenda R. (2005). Genetic parameters for female fertility traits and a fertility index in Spanish dairy cattle. J. Dairy Sci., 88: 3282-3289.

H a y e s J.F., C u e R.I., M o n a r d e s H.C. (1993). Estimates of repeatability of reproductive measures in Canadian Holsteins. J. Dairy Sci., 75 : 701-706.

H e r b e r t S., B h a t n a g a D D.S. (1989). A note on genetic association amongst productive and reproductive traits in Karan Swiss cows. Indian J. Dairy Sci., 42: 356-357.

I latsi a E.D., Muasya T.K., Muhuyi W.B., Kahi A.K. (2007). Genetic and phenotypic parameters and annual trends for milk production and fertility traits of the Sahiwal cattle in semi arid Kenya. Trop. Anim. Health Prod., 39: 37-48.

J a i r a th L.K., H a y e s J.F., C u e R.I. (1995). Correlation between first lactation and lifetime performance traits of Canadian Holsteins. J. Dairy Sci., 78: 438-448.

Javed K. (1999). Genetic and phenotypic aspects of some performance traits in a purebred herd of Sahiwal cattle in Pakistan. Ph.D. Thesis, University of Agriculture Faisalabad, Pakistan.

K a d a rmide en H.N., Thom p s on R., Coffey M.P., K o s s a ib a t i M.A. (2003). Genetic parameters and evaluations from single- and multiple-trait analysis of dairy cow fertility and milk production. Livest. Prod. Sci., 81: 183-195.

K a d a r m i d e e n H.N. (2004). Genetic correlations among body condition score, somatic cell score, milk production, fertility and conformation traits in dairy cows. Anim. Sci., 79: 191-201.

K hal il M.H., A b d e 1 G i 11 M.F., H a m e d M.K. (1994). Genetic aspects and adjustment factors for lactation traits of Friesian cattle raised in Egypt. Egyptian J. Anim. Prod., 31, p. 65.

K h a n U.N., O ls s on A., Philips s on J., Han g s a n e t K. (1992). Sahiwal breed development in Pakistan. Proc. Sixth Anim. Sci. Congress, 1: 171-178.

K h a t t a b A.S., A t i 1 H. (1999). Genetic study of fertility traits and productive in a local born Friesian cattle in Egypt. Pakistan J. Biol. Sci., 2:1178-1183. 
K u mar R., Bhatnagar D.S. (1989). Direct and correlated response of some economic traits in Karan Swiss cows. Indian J. Anim. Sci., 59: 164-166.

K u mlu S. (2003). Hayvan Islahı, 2. Baskı, Türkiye Damızlık Sığır Yetiştiricileri Merkez Birliği Yayınları, Ankara, pp. 27-33.

K u m l u S., A k m a n N. (1999). Türkiye Damızlık Siyah Alaca Sürülerinde Süt ve Döl Verimi. Lalahan Hay. Araş. Enst. Derg., 39: 1-15.

L a r a B.A., N u n e z D.R., M a r 1 n e z H.O. (1989). Selection of Holstein cows for daily yield during the intercalving period. Revista Chapingo, 14: 65-66, 24-27; 27 Ref.

Makgahlela M.L., Banga C.B., Norris D., Dzama K., Ngambi J.W. (2007). Genetic correlations between female fertility and production traits in South African Holstein cattle. S. Afr. J. Anim. Sci., 37: 180-188.

Makuza S.M., Mc Daniel B. (1996). Effects of days dry, previous days open, and current days open, on milk yields of cow in Zimbabwe and North Carolina. J. Dairy Sci., 79, p. 702.

M'Hamdi N., A loulou R., Bra K.S., Bouallegue M., Hamouda B.M. (2011). Phenotypic and genetic parameters of reproductive traits in Tunisian Holstein cows. Revist. Cient. UDO Agrícola, 11: 167-173.

M e y e r K. (1984). Estimates of genetic parameters for milk and fat yield for the first three lactations in British Friesian cows. Anim. Prod., 38: 313-322.

M e n e n d e z B.A., D e m p fle L. (1998). Genetic and environmental factors affecting some reproductive traits of Holstein cows in Cuba. Anim. Breed. Abst., 66, p. 390.

Min i t a b (1998). MINITAB Reference Manual for Windows. Release 12. Stage College, Pennsylvania, Minitab Inc.

Mis s a njo E., I m b a y a r w o - Ch i k o s i V., H a 1 i m a n i T. (2013). Estimation of genetic and phenotypic parameters for production traits and somatic cell count for Jersey dairy cattle in Zimbabwe. ISRN Veterinary Sci., 2013, Article ID 470585, 5 pages http://dx.doi.org/10.1155/2013/470585.

Muir B. L., F atehi J., Schaeffer L.R. (2004). Genetic relationships between persistency and reproductive performance in first-lactation Canadian Holsteins, J. Dairy Sci., 87: 3029-3037.

O j a n g o J.M.K., P o 11 o t G.E. (2001). Genetics of milk yield and fertility traits in Holstein-Friesian cattle on large-scale Kenyan farms. J. Anim. Sci., 79: 1742-1750.

O z y u r t A., A k m a n N. (2009). Süt sığırlarında damızlık değerinin hesaplanmasında farklı yöntemlerden yararlanma olanakları ve çeşitli parametrelerin tahmini (in Turkish). Tekirdağ, J. Agri. Sci., 6: $273-282$.

P tak E., Bus M., Morec Kopec M., Zarnecki A. (2001). Estimates of genetic parameters of milk traits using REML and Gibbs sampling. J. Anim. Feed Sci., 10: 559-567.

R e g e J.E.O. (1991). Genetic analysis of reproductive and productive performance of Friesian cattle in Kenya. J. Anim. Breed. Genet., 108: 412-423.

R e h m a n Z.U., K han M., Bhatt 1 S.A., I q b a 1 J., I q b a 1 A. (2008). Factors affecting first lactation performance of Sahiwal cattle in Pakistan. Arch. Tierzucht, 51: 305-317.

Rek lewski Z., Łukaszew icz M., Dymni cki E., Oprzadek J. (2004). Genetic quality of dairy cows vs culling reasons. Pr. Mat. Zoot., 61: 45-57.

Sahin A., Ulutaş Z., Y $11 \mathrm{maz}$ Adkinson A., Y $11 \mathrm{maz}$ Adkinson R.W. (2012). Genetic and environmental parameters and trends for milk production of Holstein cattle in Turkey, Ital. J. Anim. Sci., 11: 242-248.

S a w a A., K r e z e l- C z o p e k S. (2009). Effect of first lactation milk yield on efficiency of cows in herds with different production levels. Arch. Tierzucht, 52: 7-14.

Sharm a A.P., Khan F.H., J a dhaw S.R. (1987). Genetic study of first lactation yield in Sahiwal cows. Indian Vet. J., 64: 770-774.

S ing M., Cha u dhary R.P., S ing R.V., S ing C.V. (1988). A genetic study of part lactation production on Sahiwal cows. Indian J. Anim. Sci., 58: 860-861.

S in g M.K., S h a r m a R.C., G u p t a A.K. (1995). Genetic parameters of first lactation traits in Karan Swiss cattle. Indian J. Dairy Sci., 48: 82-84.

S in g h N.P., D e b S. M., M e h r o tra S. (1997). Performance of Holstein cattle in temperate hills in India. Indian J. Dairy Sci., $50: 7-11$.

S w a lve H., Van V l e c k L.D. (1987). Estimation of genetic (co)variances for milk yield in first three lactations using an animal model and restricted maximum likelihood. J. Dairy Sci., 70: 842-849. 
Tekerli M., Kocak S. (2009). Relationships between production and fertility traits in first lactation and life time performances of Holstein cows under subtropical condition. Arch. Tierzucht, 52: 364-370.

Tilki M., C o lak M., S a r 1 M. (2009). Genetic parameters of 305-day milk yield for Brown Swiss reared in the Bahri Dağdaş International Agricultural Research Institute in Turkey. Kafkas Üniv. Vet. Fak. Derg., 15: 397- 400.

To g h i a n i S. (2012). Genetic relationships between production traits and reproductive performance in Holstein dairy cows. Arch. Tierzucht, 55: 458-468.

To sh J.J., Ke m p R.A. (1994). Estimation of variance components for lambs weight in three sheep populations. J. Anim. Sci., 72: 1184-1190.

TUIK (2013).TUIK-Türkiye İstatistik Kurumu Hayvancılık İstatistikleri. http://www.tuik.gov.tr/PreHaberBultenleri.doid=1979preistatistikTablo.doistab id=140, 141 and 487. Accesssed: 25.2.2013.

Tuzemen N., Yanar M., Aydın R., Akbulut Ö., Yüksel S., Turgut L., Bayram B., $\mathrm{G} \ddot{\mathrm{u}} \mathrm{e}$ r O. (1999). Estimates of genetic and phenotypic parameters of milk production characteristics of Holstein cows raised in the farm of Agricultural College at Atatürk University. Proc. '99 Livestock Int. Congr., İzmir, Turkey, pp 181-185.

Ulutaş Z., Efil H., Bakır B. (1999). Estimation of variance components, genetic parameters and breeding values of milk yield for Holsteins. Proc. '99 Livestock Int. Congr., İzmir, Turkey, pp. $175-180$.

U 1 u t a ş Z., Ş a h in A., S a a t c 1 M. (2008). Genetic parameters of milk yield in Jersey cows. J. Appl. Anim. Res., 34: 29-32.

Un a lan A., Ce bec i Z. (2004). Estimation of genetic parameters and correlations for the first three lactation milk yields in Holstein Friesian cattle by the REML Method. Turk. J. Vet. Anim. Sci., 28: 1043-1049.

Un a l a n A., Ç a n k a y a S. (2010). Genetic parameters and correlations for lactation milk yields according to lactation numbers in Jersey cows. Kafkas Univ. Vet. Fak. Derg., 16: 995-1000.

Ve e r k a m p R.F., K o en en E.P.C., D e Jong G. (2001). Genetic correlations among body condition score, yield, and fertility in first-parity cows estimated by random regression models. J. Dairy Sci., 84: 2327-2335.

Vis s che r P.M., Thom p s on R. (1992). Univariate and multivariate parameter estimates for milk production traits using an animal model. I. Description and results of REML analyses. Genet. Sel. Evol., 24: 415-430.

Wa 11 E., B r o th er s to ne S., Wo o 11 i a m s J.A., B a n o s G., C o f f e y M.P. (2003). Genetic evaluation of fertility using direct and correlated traits. J. Dairy Sci., 86: 4093-4102.

Zavadilová L., Štípková M. (2012). Genetic parameters for fertility, production and longevity of Holstein cow in the Czech Republic, http://www.eaap.org/Previous_Annual_ Meetings/2012Bratislava/Papers/Published/28_Zavadilova.pdf. Accessed: 16.10.2013).

Z u l k a d i r U., B o z te p e S. (2003). Konuklar Tarım İşletmesinde Yetiştirilen Esmer Sığırların Bazı Verım Özelliklerinin Fenotipik ve Genetik Parametreleri II. Genetik Parametreler. S.Ü. Zir. Fak. Derg., 17: $74-78$.

Received: 28 VII 2013

Accepted: 25 III 2014 